\title{
THE IMPACT OF KNOWLEDGE MANAGEMENT AND HUMAN RESOURCES STRATEGIES ON THE NEPALESE BANKS' EFFICIENCY
}

\author{
Manoj Kumar Chaudhary ${ }^{1}$ \\ ${ }^{1}$ Central Department of Management, Tribhuvan University, Kathmandu, Nepal \\ e-mail: manoj86385@yahoo.com
}

Received: 01 September 2020; Accepted: 13 November 2020; Published: 18 January 2021

\begin{abstract}
The application of strategic relationship between Knowledge Management and Human Resource Strategy in Banking Industry is a key to achieve organizational competence. The main purpose of this study is to find out relationship between KM and HR Strategy for performance implication in Nepalese commercial banks. Therefore, Strategic relationship between KM and HR strategy for banking performance is found to be poor in practice. So, weak implementation hinders in achieving the desired results. Result of this study clearly exposed that Nepalese Commercial Banks need to determine different profiles of their organizational strategy based on the human resource that has the material impact on an organization. Meanwhile, it need to direct the knowledge management strategy resource which may enable Nepalese banks to achieve competitive advantage. Therefore, future efforts by both policy makers and academicians are still unknown to sharpen the theoretical framework and practical validation.
\end{abstract}

Key words: Knowledge management, Human Resource, Strategy, performance, skills, banking industry, Nepal

JEL classification: G21, J54, E50

Citation:

Chaudhary M.K. 2021. The impact of knowledge management and human resources strategies on the Nepalese banks' efficiency. Access to science, business, innovation in digital economy, ACCESS Press, 2(1): 78-90. https://doi.org/10.46656/access.2021.2.1(6)

\section{INTRODUCTION}

\section{Background}

Knowledge management (KM), which has become significant for the corporate sector, has undoubtedly become an important area of the study among academicians and practitioners. It is considered as a valuable strategic asset that can provide proper competitive advantage and nimble agility for company's action-oriented activities (Adell, 2008). In an organizational setting, benefits can occur at two levels: individual and organization (Cong \& Pandya, 2003). At the individual level, KM provides employee opportunities to enhance skill and experience. The enrichment happens through working together and sharing with each other knowledge, thereby improving overall personal performance, which leads to better career advancement. KM has been implemented and practiced in both public and private sectors and many accruing benefits have been claimed in the literatures. 
In the current competitive environment, knowledge management refers to the process of capturing the collective expertise and intelligence in an organization and to their use in facilitating innovations through continued organizational learning (Nonaka, 1991; Davenport and Prusak, 1998). In the past 20 years, KM has led to new technological improvements as well as developments of new concepts. If used properly, KM can help organizations become more flexible as well as better learning places. $\mathrm{KM}$ is expected to improve and create competitive advantages for business enterprises. Present day organizations concentrate on adapting to the concept of knowledge sharing between the different departments an adaptation that help to reduce cost and time, and improve their operational efficiency. Such an objective may be achieved by developing a KM strategy to help the organization maintain or re-establish its competitive thrust. In this sense, this approach focuses on the importance of firms' specific competence in their strategy and performance. But despite the strategic role of overlooked in distinct benefits, the knowledge has been overlooked many knowledge managements projects and initiatives, and KM has been considered by many organizations as a "stand alone" project that is planned, initiated and operated in an isolated environment. There are already a large number of KM activities consciously or unconsciously implemented in organization. Many of these implementations are failures due to the lack of the ability to align KM with the organization in terms of human resource strategies in the form of employee competence and technological resources (Zack, 2002; Maier and Remus, 2002; Smith, 2007; Adhikari, 2010). What this means is that knowledge can exist within five primary contexts that influence how KM initiatives impact on organizational performance. These include strategic context, knowledge context, organizational context, human context, and technological context. An effective use of knowledge to derive competitive advantage can be achieved by a holistic approach that covers knowledge management strategy and human resource strategic factors in terms of employees' knowledge and skill.

A fit among HRM practices in terms of skills and competencies (i.e., interpersonal and communication, leadership, and vocational and professional skills) can augment employee performance and enhance company's core competitive advantages (Stowe, 2010). The importance of HR strategy in terms of skill and capability has been noted. The successful implementation of KM is integral to corporate HR strategies in terms of skills and competences which significantly tell upon organizational member's attitudes, beliefs, values, and overall work systems. It plays an important role in facilitating employee absorption, transfer, sharing and creation of knowledge about organizational goals. Therefore, HR skill and competence in terms of interpersonal and communication, skills, leadership skills and vocational and professional skills affect employees' motives and behaviors towards work and performance in participating KM activities in an organization (Chaudhary, 2009). It must be noted that enough exceptions are 
attributed to knowledge management and human resource strategies in terms of skills and competencies which are crucial for organizational performance (Adhikari, 2010).

Based on this kind of literature, it is reasonable to assert that in order to facilitate the implementation of KM initiatives and achieve corporate objective, KM strategy must be aligned with HR strategy because managerial skills play a significant role in an organization's effectiveness. Furthermore, it can be also noticed that the knowledge and competence of human resource as valuable assets for firms because of their characteristic of being firm-specific, socially complex and path-dependent (Wright \& Snell, 2000). As prior research clearly points out, the ownership type is a key variable affecting strategic alignment practice and organizational performance configurations (Jiang et. al., 2013). Therefore, given these differences, this study assumes different ownership patterns to have different preferences regarding the practice of strategic alignment among KM, and HR strategies to achieve performance.

Moreover, so far as the importance of the application of KM in banking industry is concerned, for last 20 years banks have been actively automating their manual process. This scenario has been changing fast. More efforts and resources are being employed to make automatization, as successful in today's modern banking, information and knowledge are treasured assets. Without proper management information systems, plans, procedures and tools, information has become a very serious and annoying problem in many banks to the extent that most of the time information is regarded as noise. Nonetheless, realizing the important roles they play in the economy, banks are trying to make it a priority to capture and manage their outdated working system and turn it into organizational knowledge or business intelligence (Ali, 2006). The globalization of financial markets has forced bankers to be knowledge-based and be more efficient in managing knowledge in their banking operations. Here it must be mentioned that the application of KM with HR strategic practices in the banking industry does not really differ from those of other industries, but the increasing competition of banking environment makes its implementation quite important (Al-Ammary, 2008; Jyoti et al., 2012; Chalise, 2012; Chaudhary, 2009).

However, so far as Nepalese perspective is concerned, very few studies have been done probe into to strategic alignment perspective between $\mathrm{KM}$ and HR strategy for organizational performance in Nepalese settings. This study, which seeks to plug this gap, takes place in the commercial banking sector because of the relevancy of strategic alignment. Therefore, the need of this study turns out to be imperative and it can be highlighted in the Nepalese Commercial banks, the existing real scenario of the current practice and relationship between KM and HR strategies for organizational performance.

Rationale of the study 
Knowledge is regarded as a resource to gain competitive advantage. Intense paceof global market competitions, consumers' awareness and technological innovations have made the market place more competitive. So, Nepalese banking organizations need to use and harness their resources not only to sustain themselves in the competitive market but also to achieve competitive advantage and innovation. For this, they require well defined organizational strategy for which they must obtain comprehensive information about how KM strategy is managed and utilized strategically. Only then, they may consolidate strongly their position in the global market. In the era of globalization, a firm's competitiveness depends on its capacity to manage performance through the development of skills and competencies of its employees (Adhikari, 2010).

The literature focusing on the environment of banking industries on the subject of managerial skills in every type of organization is extensive. There is an overwhelming consensus that businessrelated leadership abilities, interpersonal and communication skills as well as vocational and professional skills and functional abilities remain critically important ingredients for success in managing the banking industry. However, there is strong evidence of concern among practitioners that an exclusive focus on the quantitative analysis, functional specialization and calculative rationality of the "bottom line" may not adequately prepare new managers to be adaptive, collaborative and team builders (Stowe, 2010). It is because every business sector will have to seek, hire and retain highly qualified and professional individuals that have a breadth of knowledge of both business and banking institutions in order to remain competitive. For this purpose, organization must recruit, hire and train individuals that possess a multitude of managerial skills (Hurley \& Brewer, 1991).

In the last 100 years, technology has blossomed as never before and as a result, managers often encounter a situation that puts stress and strain on their managerial abilities (Griffiths, 2007). Their inexperience and lack of specific knowledge result into a resounding lack of leadership among organizational professionals. Lack of managerial development and skill often lead to employee frustration, disenfranchisement from the organization, and in some cases retention problem is faced by organization especially in-service sectors like banks. (Weston et al., 2008). An essential determinant of organizational performance is managerial skill relating to leadership, communication, and vocational and professional areas. Furthermore, both knowledge and strategic orientation in organization for an overall performance are influenced by leadership skill, interpersonal skill and communication skill as well as vocational and professional skills. (Shewchuck et al., 2005).

Understanding and implementing $\mathrm{KM}$ initiative require the development and nurturance of relationship, awareness and, in general, a common ground amongst organizational members. KM is the systematic and explicit management of knowledge-related activities, practices, programs and policies within enterprises (Wiig, 1999). This approach views knowledge as a process and a complex set of dynamic skills, knowhow, etc. that are constantly changing. This approach tends to view the 
"knowledge problem as a management issue. Knowledge management is not simply a matter of managing information, $\mathrm{KM}$ is essentially a deeply social process, which must take into account human and social factors" (Clarke \& Rollo, 2001; Thomas et al., 2001).

It is clearly noticed that without formal preparation for management and responsibilities as well as lack of skills such as leadership skills, interpersonal and communication skills and vocational and professional skills managers learn by trial and error. This situation results into a frequent mishandling of issues relating to both the employees and the organizations which cause both managers and the employees to become disappointed at the work place, becomes the ultimate casualty organizational performance. The adverse effect has additional bearing on the management of relationship, the clarity of communication, the ability to create working environments and excellence in practices (Stowe, 2010). Literature review on the topic reveals that knowledge management strategies as well as human resource strategy in terms of interpersonal and communication skills, leadership skills and vocational and professional skills are interdependent and they mutually influence on organizational performance (Adhikari, 2010; Stowe, 2010).

Moreover, based on the findings of previous research, there are several examples of strategic alignment practice between KM and HR strategies which have been noted in general and in the banking industry inparticular:

- World Bank is one of the important players in KM application. According to World Bank, KM is the latest strategy in increasing organizational competitiveness. An identification of relevant know-how was identified that can then be captured and created into the knowledge base and it is made accessible to all staff. Relevant part of the system is now becoming attainable externally, so that client's partners and stakeholders around the world will be able to have access to the know-how of the organizations. For example, an Indonesian official needed to know the international experience on private sector involvement in vocational training through the help of the human development networks, the relevant task team leader was able to give to the official within a short time frame a comprehensive analysis of the international knowledge and experience (Ali, 2006)

- When Swedish insurance giant, Skandia, expanded its points of sale from 5,000 to 50,000 in less than five years, senior management began looking for a more effective and efficient manner of transferring knowledge and increasing its use throughout its global operations. It has leveraged internal know-how to dramatically reduce start up time for new ventures to seven methods, compared to an industry average of seven years (Ali, 2006).

- Bank of Montreal is a leader in customer-centric knowledge-based solution. It is the oldest commercial bank in Canada and in 2019 generated revenues from sales of banking products and 
services in the amount of $\$ 25.5$ billion $^{1}$. This bank wanted to change the status of the traditional knowledge discovery life cycle and capture the potential benefits of improving the efficiency of turning models into production. As a result, during 2000/2001 the Bank of Montreal participated in a multimillion-dollar project that would help make the knowledge discovery process more economical, error-free and faster (Dzinkowski, 2001).

- At the end of 2019, Deutsche Bank is ranked 22nd ${ }^{2}$ in the world in terms of assets - 1450.03 billion and $8 \mathrm{th}^{3}$ in Europe in the same indicator - $\$ 1580.14$ billion as of 30.06.2020. It has embraced the strategy of continuous, concentrated corporate learning and intellectual capital branding through its creation of the Deutsche Bank University (DBU). DBU is in initial stage of development, and to a large degree, follows the thinking of what are recognized by industry experts as best practices in developing a corporate university as an umbrella organization for learning (Dzinkowski, 2001).

Tiger Bank, the largest commercial bank in Malaysia, is amenable to the knowledge management. The findings of Ali and Ahmad (2006) suggest that some of the environmental factors that have compelled the bank to go in for knowledge management were: (a) the need to maintain customer knowledge (customer relation management (CRM) (b) competitive intelligence, and (c) service knowledge. Thus, knowledge management initiatives have been found to be important for maintaining the banks' competitive edge as well as their proprietary knowledge.

In Nepal, Nepalese bankers and decision makers are now facing a number of challenges, both national and international. Since 1990, Nepal has been pursuing a number of reform policies. The CRANET survey conducted for the first time in Nepal in 2004 AD in 205 different organizations developments responsibilities indicates some in HR roles and Development of employees' and managers' skills such as interpersonal and communication skills, leadership skill, vocational and professional skills are essential for organizational performance in Nepalese organizations. With the restoration of democracy, the growth of banking sector is much better compared to other sectors. The Government of Nepal has initiated and major reform policy to promote manufacturing and service sectors and their competitive powers. The introduction of liberalization and its reform policy in 1990s and the new industrial policy of 1992 gave an emphasis to deregulation, encouraging competition and placing a reliance on market forces in the allocation of resources.

The government has encouraged domestic and foreign investors through measures such as licensing tax facilities, foreign direct investment (FDI), and other institutional arrangements. The government has also made efforts to encourage private investors to increase investment in the country and to bring in managerial and technical skills, modern technology and foreign capital

\footnotetext{
${ }^{1}$ https://www.advratings.com/companies/bank-of-montreal

2 https://www.advratings.com/banking/top-100-banks

3 https://www.advratings.com/banking/top-banks-in-europe
} 
(Adhikari, 2010). Over the past 20 years, Nepalese banking industries have grown rapidly in terms of business volume and market size (Gautam, 2007). In relation to the service sectors, a recent investigation into the transaction of some public sector banks and private banks shows how these banks have incurred huge losses and face serious challenges due to politically driven, incapable governance, mis-managed workers' union and weak human resource management practice, inadequately skillful workforce and alike (HMG of Nepal, 2000). As far as the productivity of Nepalese banking industries, a bank must be sure of its position in the competitive market and of its HR - practices for defending and gaining current market share under complex situation. So, to be effectively sustainable in the market, human resource through knowledge management strategy and its effective application with upgrading capability is required (Chaudhary, 2009). The managers in the Nepalese commercial banks should pay attention to the importance of the different dimensions of knowledge management choices, diverse profiles of knowledge strategy (Chalise, 2012; Chaudhary, 2009). In addition, Nepalese banks, moreover, need to determine different profiles of their organizational strategy based on the human resource that matter the most and then direct the knowledge management strategy resource which may enable Nepalese banks to sustain their competitive advantage.

Therefore, all over the world, banks have of realized the crucial role of strategic alignment between KM and HR in gaining an edge in this competitive environment. However, there have been laggards in the adoption of knowledge management usually due to wait and see attitude of what will be the true benefits and pitfalls from early adopters. Keeping these views into consideration, there is a dearth of empirical study in this context Nepal. The Nepalese commercial banks are selected as the more appropriate contexts for the current study. A theoretical model for KM alignment with HR strategy has been built in this study based on the previously published literature on KM strategy (i.e. codification and personalization strategy) perspective and HR strategy in terms of leadership skills, interpersonal and communication skills, professional and vocational skills. Therefore, this study tries to provide new empirical evidence of strategic alignment in the field of $\mathrm{KM}$, the study has a bearing on organizational performance measured in terms of job satisfaction, commitment, individual competence, and market and financial performance.

\section{Survey Output Data}

Table 1. The composite table of sample banks, respondents and response rates.

\begin{tabular}{|l|c|c|c|c|c|c|c|}
\hline \multirow{2}{*}{ Particulars } & \multicolumn{2}{|c|}{ Public } & \multicolumn{2}{c|}{ Private } & Joint Venture & Total \\
\cline { 2 - 8 } & No. & $\%$ & No. & $\%$ & No. & $\%$ & \\
\hline Number of Sample Firms & 3 & 14.29 & 12 & 57.14 & 6 & 28.57 & 21 \\
\hline Number of Respondents & 44 & 14.62 & 166 & 55.15 & 91 & 30.23 & 301 \\
\hline Male Respondents & 31 & 15.58 & 108 & 54.27 & 60 & 30.15 & 199 \\
\hline Female Respondents & 13 & 12.75 & 58 & 56.86 & 31 & 30.39 & 102 \\
\hline Questionnaire Distributed & 64 & 15.2 & 242 & 57.48 & 115 & 27.31 & 421 \\
\hline
\end{tabular}




\begin{tabular}{|l|c|c|c|c|c|c|c|}
\hline $\begin{array}{l}\text { Number of Questionnaire } \\
\text { received }\end{array}$ & 44 & 14.62 & 166 & 55.15 & 91 & 30.23 & 301 \\
\hline Non -Response & 20 & 10.05 & 76 & 38.19 & 24 & 11.06 & 199 \\
\hline
\end{tabular}

The sample banks were selected on stratified basis of on purposive convenience sampling technique rather than just the random sampling. A total of 301 questionnaire was received out of 421. The sample finally incorporated 21 organizations and 301 respondents (44 public, 91 joint venture and 166 private banks. The final sample had a statistical margin of error of \pm 5.7 percent with a 95 percent confidence internal. Finally, the sample size of this study included organization as a unit of analysis for collection and analysis of data.

Table 2: Respondents Profile

\begin{tabular}{|c|l|c|c|c|c|c|c|c|}
\hline \multirow{2}{*}{$\begin{array}{c}\text { Number of } \\
\text { Banks }\end{array}$} & \multirow{2}{*}{$\begin{array}{l}\text { Ownership } \\
\text { Pattern }\end{array}$} & \multicolumn{7}{|c|}{ Position of Respondents } \\
\cline { 3 - 9 } & CEO & GM & $\begin{array}{c}\text { Dept. } \\
\text { Head }\end{array}$ & $\begin{array}{c}\text { Sen. } \\
\text { Officer }\end{array}$ & Officer & Total & $\%$ \\
\hline 3 & Public & 1 & 2 & 6 & 10 & 25 & 44 & 14.62 \\
\hline 12 & Private Bank & 8 & 10 & 31 & 53 & 64 & 166 & 55.15 \\
\hline 6 & Joint Venture & 3 & 7 & 15 & 29 & 37 & 91 & 30.23 \\
\hline & Total & 12 & 19 & 52 & 92 & 126 & 301 & 100 \\
\hline & $\%$ & 3.99 & 6.31 & 17.28 & 30.56 & 41.86 & & \\
\hline
\end{tabular}

Source: prepared by the author

In regard to respondent profile, junior officers followed by senior officers were major participants filling in the questionnaire. Similarly, private non-joint venture banks followed by private joint venture banks were the major participants obtained as sample having $55.15 \%$ (private banks) and $30.23 \%$ joint venture) banks in Nepal. Therefore, out of the total sample organization 14.62 percent data obtained from public banks, 55.15 from Private Banks. Similarly, 3.99 percent respondents were the CEOs of sample organization. In addition, the views of 6.31 percent of General Managers, 17.28 percent of Department Heads, 30.56 percent of Senior Officers and 41.86 percent of Junior Officers were obtained as potential responses of this study.

Table 3. Internal consistency reliability for the research model scales of knowledge management, business and HR strategies and organizational performance.

\begin{tabular}{|l|c|c|c|}
\hline \multicolumn{1}{|c|}{ Constructs } & Reliability (Alpha Value) & Item Deleted \\
\hline Knowledge Management Strategy & $\mathbf{0 . 8 6 5}$ & & Q8 \\
\hline Codification Strategy & & 0.801 & Q8 \\
\hline Personalization Strategy & & 0.857 & Q1,2,5 \\
\hline Human Resource Strategy & $\mathbf{0 . 7 8 7}$ & & Q5, 7,8 \\
\hline Leadership Skills & & 0.930 & - \\
\hline Interpersonal and Communication Skills & & 0.757 & Q5 \\
\hline Professional and Vocational Skills & & 0.882 & Q6 \\
\hline
\end{tabular}




\begin{tabular}{|l|c|c|c|}
\hline Organizational Performance & $\mathbf{0 . 7 8}$ & & - \\
\hline Job Satisfaction & & 0.738 & Q6 \\
\hline Commitment & & 0.734 & Q2,3 \\
\hline Individual Competence & & 0.841 & - \\
\hline Market and Financial Performance & 0.810 & - \\
\hline
\end{tabular}

\section{RESEARCH METHOD}

The research method adopted in the study is a descriptive-cum-exploratory design. A survey-based, selected sample of officer level employee from three categories of Nepalese commercial banks has been used to get answer of the research question and objectives. For this, the research instruments utilized consists of structured questionnaire. Sample organizations and participants have been selected on a purposive convenience sampling technique.

Therefore, based on ownership pattern out of 27 commercial banks, only 21 commercial banks are taken as sample comprising of 3 public banks, 12 private banks and 6 joint venture banks having at least an experience of five years operation. Selected banks have been visited personally for meeting with officers to fill up the questionnaire. Out of 421, only 301 questionnaires have been received and all of them are usable. Therefore, the overall potential response received is 71.49 percent which can be taken as a fair representation of the research population. Furthermore, regarding the tool for testing hypothesis, the questionnaire survey data have been inserted into SPSS version 18, and descriptive statistics include mean and standard deviation t-test and £-test, Spearman rank correlation and multiple regression analysis have been used to analyze and get answer in regard to set research questions. Furthermore, regression analysis D.W.-test and VIF-test were also used.

For each multiple regression analysis, multicollinearity analysis has been examined by computing the variance inflation factors (VIF) for all independent and dependent variables. For five regressions, the highest VIF value is 4.893 , which is well below the acceptable cut off value 10 . The below of 10 VIF value indicates that multicollinearity does not constitute a problem in regression analysis (Gujrati and Sangeetha, (2010); Jiang, et. al., (2013). Therefore, the decision to proceed with regression analysis in this study is justified.

\section{RESULT AND ANALYSIS}

The alignment among business strategy, knowledge management strategy and HR strategy contributes positively $(\mathrm{p}<0.000, \mathrm{p}<0.047$ and $\mathrm{p}<0.000)$ to overall organizational performance, which explain $57.3 \%$ of its total variance (Adjusted $\mathrm{R}^{2}=0.573$ ).

KM strategy, contributes the most to the prediction of job satisfaction. Similarly, the level of employee commitment in Nepalese commercial banks is found at an average level. However, the role of the manager in enhancing their employee's commitment toward job and organization itself requires attention. Moreover, the alignment between KM and HR strategies contribute positively to individual competence for an explanatory 
relationship and explain 40.04 of its total variables (Adjusted R" - 0.400). This is a satisfactory level effect. This means the Nepalese banks officers know the benefit of alignment between KM and HR strategies for the development of employees' competencies level: they believe in team work, the delegation of authority, know about different mode of training program and understand about the different approaches of leadership but have less knowledge management practice' about human resource planning and proper way in regard to their business approaches. In respect of market and financial performance, the alignment among Business, KM and HP strategies contributes positively to market and financial performance in Nepalese commercial banks. However, the role of leadership in motivating the subordinates and allocating their necessary resources towards attaining market and financial performance is found to be less attractive. The investment in human capital, IT, infrastructure, $\mathrm{R} \& \mathrm{D}$ program towards product and service quality and innovation require more attention on the part of commercial banks of Nepal.

Table 4. Multiple Regression Analysis, Variable (No - 301) VIF Value - $4893<10$

\begin{tabular}{|l|l|c|c|c|c|c|}
\hline Variable & \multicolumn{1}{|c|}{ Models } & R2 & Adj. R2 & F-value & P-value & D.W. \\
\hline DV.YP & $\begin{array}{l}Y P=\alpha 0+\beta 1 \mathrm{X} 1+\beta 2 \mathrm{X} 2+\mathrm{e} 1 \\
Y P=26.042+0.273 \mathrm{X} 1+0.310 \mathrm{X} 2 \\
(0.000)\end{array}$ & 0.581 & 0.578 & 206.43 & 0.000 & 1.803 \\
\hline DV.JS & $\begin{array}{l}Y J S=\alpha 0+\beta 1 \mathrm{X} 1+\beta 2 \mathrm{X} 2+\mathrm{e} 1 \\
Y J S=2.699+0.114 \mathrm{X} 1+0.049 \mathrm{X} 2 \\
(0.000)\end{array}$ & 0.353 & 0.349 & 81.409 & 0.000 & 1.832 \\
\hline DV.YC & $\begin{array}{l}Y C=\alpha 0+\beta 1 \mathrm{X} 1+\beta 2 \mathrm{X} 2+\mathrm{e} 1 \\
Y C=5.504+0.053 \mathrm{X} 1+0.057 \mathrm{X} 2 \\
(0.032)\end{array}$ & 0.280 & 0.275 & 57.979 & $0.000 \cdot$ & 1.687 \\
\hline DV.YIC & $\begin{array}{l}Y I C=\alpha 0+\beta 1 \mathrm{X} 1+\beta 2 \mathrm{X} 2+\mathrm{e} 1 \\
Y I C=8.352+0.067 \mathrm{X} 1+0.100 \mathrm{X} 2 \\
(0.044)\end{array}$ & 0.404 & 0.400 & 100.85 & 0.000 & 1.645 \\
\hline DV.YMFP & $\begin{array}{l}Y M F P=\alpha 0+\beta 1 \mathrm{X} 1+\beta 2 \mathrm{X} 2+\mathrm{e} 1 \\
Y M F P=12.046+0.095 \mathrm{X} 1+0.144 \mathrm{X} 2 \\
(0.019)\end{array}$ & 0.421 & 0.418 & 108.529 & 0.000 & 1.615 \\
\hline
\end{tabular}

Source: prepared by the author

\section{CONCLUSION AND IMPLICATION}

Based on the result, the study concludes that KM strategy by itself has been found to be less effective in Nepalese commercial banks. Therefore, the use of KM for increasing market share and financial performance though innovation is still in transition and at a developing stage. Neither the banks have the systematic approach of KM strategy nor do they use appropriate practice for strategic alignment. In addition, Nepalese 
banks have policy to improve their employees' capacity to respond to the changing environment and to go for innovation but poor implementation hinders in achieve the desired results. It is clear that the HR professionals do not have the right HRM knowledge and skills required for the job. The alignment between KM and HR strategies for performance is found to be in poor practice in the banking sectors Nepal. Along with the alignment among these predictors, other factors like environmental factors, leadership unions and rewards management are very important ones for attaining higher performance. Job satisfaction among public, joint venture banks employees is not at same 1evel. Joint venture and public employees are found to be more satisfied than their private banks counterparts in Nepal. Apart from salary and benefits, management of private banks provides job security and stability with required autonomy to increase level of satisfaction.

Public banks employees are found to show lower-level commitment towards their job than joint venture and private banks despite being relatively more satisfied. This shows that satisfaction alone does not ensure commitment. Therefore, authorities of Nepalese public banks need to give more attention towards empowering their employees by providing career and job-oriented training efforts, incorporating their feeling expectation, holding regular meeting about their job performance, and alike. The different categories of owners have differential influence on job satisfaction, commitment, individual competence and market and financial performance in Nepal. The result points out that the overall performance depends as a firm's environmental situation, availability of resources, source of innovation, competitive advantage, regulatory procedure, organizational structure, degree of emphasis on $R \& D$, and soon. Managers of Nepalese commercial banks pay less attention towards, empowering their subordinates, meeting their expectation, understanding their internal feelings, regular meetings and proper communication about their job performance. Nepalese commercial hanks are highly oriented towards formulation of business strategy and long-term programs to be faced by the back but less oriented towards designing human resource planning in regard to individual employee competence.

Nepalese Commercial Banks are required to prepare and develop their managerial skills, so that these banks are able to compete with others in competence and productivity. Therefore,

- a long-term policy is required for managing people's knowledge, skills and experience that must be integrated with business objective;

- the officer level staff should be sent to attend competency development programs (CDPs) and workshops so that they have clear idea about their managerial roles in responding future opportunities and challenges;

- the competencies of the Nepalese Banks managers can be strengthened when they are involved by the banks in the decision-making process. Likewise, individual competence can be further enhanced through knowledge sharing culture, training, workshop and CDPs program so that they can easily assess the knowledge and skills as per the needs.

The Nepalese commercial banks should conduct training and seminars on a regular basis to familiarize the employees with the specific objectives of the banks and involve the managers in strategy formulation 
process so that they will be able to design proper staffing plans and can take right decisions related to HR issues and practices. Thus, this study provides clear understanding of KM strategy alignment with HR strategy in Nepalese commercial banks and helps to rethink their ideas and methods of managing their tangible and intangible assets. So, the findings of this research provide new vistas for policy makers and academicians to know how important strategic alignment is in the field of knowledge management.

Therefore, future efforts are still required to strengthen the theoretical framework and assess it by empirical validation. Furthermore, this study motivates to all the involved and interested people to understand the importance of human competencies. Therefore, this is considered as a new contribution.

\section{Conflict of interests}

The authors declare no conflict of interest.

\section{References}

Adell, M. (2008). A theoretical framework for strategic knowledge management maturity model: from systematic approach. Retrieved from https://www.scribd.com/doc/74376856

Adhikari D.R., (2008). Labour Legislations for Improving Quality of Work Life in Nepal. Paper presented in the Indian Society for Labour Economics (ISLE), Giri Institute of Development Studies, Lucknow, India, 13-15, December.

Adhikari, D.R. (2010). Human resource development (HRD) for performance management: The case of Nepalese organizations. International Journal of Productivity and Performance Management, 59(4), 306-324.

Adhikari, D.R. (2004). Human Resource Environment in Nepal. Paper presented at the 5th International Industrial Relation Association Congress, Seoul.

Adhikari, D.R., (2007). Empowering Nepalese Managers for Organizational Performance. Paper presented at 12th International Colloquium of Asia Pacific Researchers in Organizational Studies (APROS), Management Development Institute (MDI), Gurgaon, India, 9-12 December.

Adhikari, D.R., (2008). Performance Management and Human Resource Development. International Workshop on Globalization and Human Resource Management, Mahatmagandhi Labour institute, Ahmedbaad, Gujrat, India.

Al-Ammary, J.H. (2008). Knowledge management strategic Alignment in the banking sector at cooperation council (GCC) countries, School of Information Technology, Ph.D. thesis, Murdoch University Western Australia. Viewed 29 November, 2008.

Ali, H. A. (2006). Knowledge management in Malaysian banks: A new paradigm. Journal of Knowledge Management Practice, 1-12.

Chalise, M. (2012). Knowledge Management: A Comparative Study of Public and Private Sector Commercial Banks in Nepal: Unpublished Ph.D. Thesis. Faculty of Management, Tribhuvan University, Nepal.

Chaudhary, M.K. (2009), Strategic Alignment of Knowledge Management and Corporate Strategies in Nepalese Banking Industry, A Journal of Management, Vol. 1, PP. 57-72.

Clarke, T. \& Rollo, C. (2001). Corporate initiatives in knowledge management. Education and Training, 43 (4/5), 206214.

Cong, X., Pandya, K.V. (2003). Issues of Knowledge Management in the Public Sector. Retrieved 10 September, 2002 from http://www.ejkm.com.

Davenport, T.H. (2005). Thinking for a Living: How to Get Better Performance and Result from Knowledge Workers. Boston: Harvard Business School Press.

Davenport, T.H. \& Prusak. L. (1998). Working Knowledge:How Organizations Manage What they Know. Harvard Business School Press, Boston, MA.

Dzinkowski, R. (2001). Knowledge Management in Financial Services: Leveraging intellectual capital to maximize shareholder value, London: Lafferty Publication Ltd. 
Gautam, D. (2007). Integration and development of human resources practices in Nepal. www.emeraldinsight.com/01425455.htm, 29(6), 711-726.

Griffith, J.R. (2007). Improving preparation for senior management in healthcare. The Journal of Health Administration Education, 24 (1), 11-32.

Gujarat, D.N. \& Sangeeta, (2010). Basic Econometrics (Eds. 4). Tata McGraw Hill Education Private Limited, New Delhi, India.

Hurley, R.E., \& Brewer, K.P. (1991). The continuing care retirement community executive: manager for all seasons. Hospital \& Health Service Administration, 36(3), 365-381.

Jiang, L., Waller, D. \& Cai, S. (2013). Does Ownership type matter for innovations? Evidence from China. Journal of Business Research, 1-6.

Jyoti, J., Rani, R. \& Gupta, T. (2012). SHRM orientation of Bank Manager: Role of Tack knowledge conceptual skills, Business awareness and HRM competence, available at: www.hrm12.nfle.in/files.pdf, assessed on 17th February, 2012.

Maier, R. \& Remus, U. (2002). Defining process-oriented knowledge management strategies. Knowledge and process management, 9 (2), 103-118.

Nonaka, I. (1991). The Knowledge creating company. Harvard Business Review, November-December, 96-104.

Shewchuk, R.M., O'Connor, S.J, \& Fine, DJ. (2005). Building an understanding of the competencies needed for health administration practice. Journal of Healthcare Management/America College of Healthcare Executives, 50 (1) 3247; discussion 48

Smith, P. S.S. (2007). Leadership and learning facilitating self-directed learning in enterprises. Journal of European Industrial Training, 31(5), 324-335.

Stowe, M. H. (2010). Required knowledge, skills and abilities from healthcare clinical managers' perspectives. Academy of Health Care Management Journal, 6(2), 57-74.

Thomas, J.C., Kellog. W.A. \& Erickson, T. (2001). The knowledge management puzzle: human and social factors in knowledge management. IBM Systems Tournal, 40 (4), 863-884.

Weston, M., Falter, B., Lamb, G., Mahon, g., Malloch, K., Provan, K., Roe, S., et.al. (2008). Health Care Leadership Academy: A statewide collaboration to Enhance Nursing Leadership Competencies. The Journal of Continuing Education in Nursing, 39 (10), 468.

Wiig, K.M. (1999). Introducing knowledge management into the enterprise, in Liebowitz, J. (Ed.). Knowledge Management Handbook, CRC Press, Boca Raton, FL. 1-41.

Wright P.M. \& Snell, S.A. (2000), Toward a Unifying Theory for Exploring fit and flexibility in Strategic Resource Management. Academy of Management Review, 23, 756-772.

Zack, M.H. (2002). Epilouge: developing a knowledge strategy, in Bontis, N and Choo, CW. (Eds.). The Strategic Management of Intellectual Capital and Organizational Knowledge, Oxford University Press, Oxford, 268-276.

\section{About the author:}

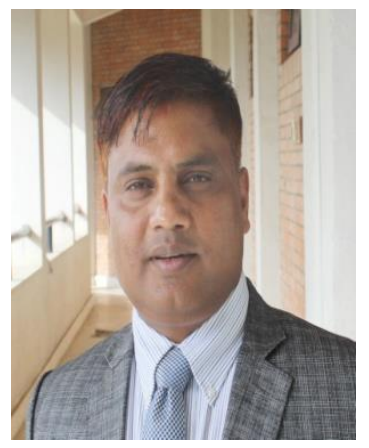

\section{Manoj Kumar CHAUDHARY}

PhD, (Management), associate professor, Central Department of Management Tribhuvan University, Kathmandu, Federal Democratic Republic of Nepal.

Research interests: Entrepreneurship, Management, HR, Corporate Governance and CSR, Business and Economics Etc.

ORCID ID: https://orcid.org/0000-0003-4515-6319

Copyright $(2020$ by author(s) and ACCESS Publishing Press This work is licensed under the Creative Commons Attribution International License (CC BY) 